\title{
EVALUATION OF SPORTS ABILITY TO IMPROVE PATIENTS WITH PULMONARY DISEASE
}

\author{
AVALIAÇÃODA HABILIDADENO ESPORTE PARA A MELHORIA DEPACIENTESCOM DOENÇA PULMONAR \\ EVALUACIÓN DE LA HABILIDAD ENEL DEPORTEPARA LAMEJORIÁA DEACIENTES CONENFERMEDADPULMONAR
}

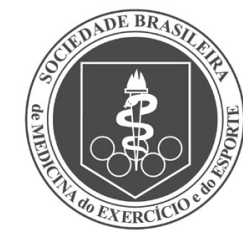

Original Article ARTIGO ORIGINAL Artículo Original

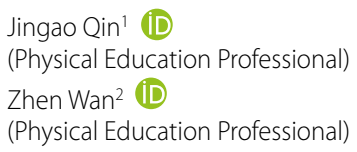

1. Suwon University, Hwaseong, Gyeonggi Province, Korea.

2. Kyung Hee University, Yongin-si, Gyeonggi-do, Korea.

\section{Correspondence:}

Zhen Wan

Yongin-si, Gyeonggi-do, Korea.

17104.ZhenWan7@126.com

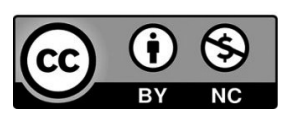

\begin{abstract}
Introduction: Chronic obstructive pulmonary disease (COPD) is one of the most common diseases in the lungs. Objective: To evaluate the clinical effect of respiratory rehabilitation training combined with Traditional Chinese and western medicine on the clinical treatment of motor function in patients with COPD. Methods: 156 patients with chronic obstructive pulmonary disease admitted to a hospital from December 2013 to June 2015 were selected as study subjects and randomly divided into groups for treatment. Results: comparing blood gas exchange rates of patients in the four groups, the experimental group, trained using integrated Chinese and Western medicine, was significantly better than the control groups $\mathrm{A}, \mathrm{B}$ and $\mathrm{C}$, in aspects such as $\mathrm{PaCO}$, $\mathrm{PaO} 2, \mathrm{SaO} 2, \mathrm{pH}$, etc., the difference was statistically significant $(\mathrm{p}<0.05)$. The improvement of lung function in the experimental group was significantly better than in the other three groups, with statistical significance $(p<0.05)$. Conclusions: Applying Chinese and Western Medicine combined with comprehensive respiratory rehabilitation training has a significant clinical effect. It effectively improved patients'related clinical indicators and should be widely promoted. Level of evidence ll; Therapeutic studies - investigation of treatment results.
\end{abstract}

Keywords: Respiratory System; Asthma-Chronic Obstructive Pulmonary Disease Overlap Syndrome; Effects.

\section{RESUMO}

Introdução: A doença pulmonar obstrutiva crônica (DPOC) éuma das doenças pulmonares mais comuns. Objetivo: Avaliar os efeitos clínicos de treino para reabilitação respiratória somado ao uso de medicina ocidental e medicina tradicional chines a combinadas, no tratamento da função motora de pacientes com DPOC. Métodos: 156 pacientes com DPOC, hospitalizados entre dezembro de 2013 e junho de 2015, foram selecionados como objetos de estudo e aleatoriamente divididos em grupos de tratamento. Resultados: Quanto aos níveis de troca gasosa dos pacientes nos quatro grupos, o grupo experimental, treinado por meio de práticas de medicina ocidental e de medicina tradicional chinesa combinadas teve uma performance significativamente melhor que a dos grupos $\mathrm{A}$, $\mathrm{B}$, e C, em aspectos tais como PaCO2, PaO2, SaO2, pH, etc., com significância estatistica ( $p<0,05)$. A melhoria da função pulmonar no grupo experimental também foi significativamente maior que nos outros grupos, mais uma vez com significância estatística $(p<0,05)$. Conclusões: A aplicação da medicina chinesa e da medicina ocidental combinadas, somadas a um treino de reabilitação respiratória abrangente, teve um efeito clínico significativo, efetivamente melhorando indicadores clínicos relevantes. Tal aplicação deveria ser largamente promovida. Nível de evidência ll; Estudos terapêuticos - investigação de resultados de tratamento.

Descritores: Sistema Respiratório; Síndrome de Sobreposição da Doença Pulmonar Obstrutiva Crônica e Asma; Efeitos.

\section{RESUMEN}

Introducción: La enfermedad pulmonar obstructiva crónica (EPOC) es una de las enfermedades pulmonares más comunes. Objetivo: Evaluar los efectos clínicos de entrenamiento para rehabilitación respiratoria sumado al uso de medicina occidental y medicina tradicional china combinadas en el tratamiento de la función motora de pacientes con EPOC. Métodos: 156 pacientes con EPOC, hospitalizados entre diciembre de 2013 y junio de 2015, fueron seleccionados como objetos de estudio y aleatoriamente divididos en grupos de tratamiento. Resultados: En cuanto a los niveles de intercambio gaseoso de los pacientes de los cuatro grupos, el grupo experimental, entrenado mediante prácticas combinadas de medicina occidental y medicina tradicional china, obtuvo un rendimiento significativamente mejor que los grupos $\mathrm{A}, \mathrm{By} \mathrm{C}$, en aspectos como $\mathrm{PaCO} 2, \mathrm{PaO} 2, \mathrm{SaO} 2, \mathrm{pH}$, etc., con significancia estadística $(\mathrm{p}<0,05)$. La mejora de la función pulmonar en el grupo experimental también fue significativamente mayor que en los otros grupos, una vez más con significancia estadística $(p<0,05)$. Conclusiones: La aplicación de la medicina china y de la medicina occidental combinadas, sumadas a un entrenamiento de rehabilitación respiratorio abarcativo, tuvo un efecto clínico significativo, efectivamente mejorando indicadores clínicos relevantes. Tal aplicación debería ser largamente promovida. Nivel de evidencia ll; Estudios terapéuticos - investigación de resultados de tratamiento.

Descriptores: Sistema Respiratorio; Sindrome de Superposición de la Enfermedad Pulmonar Obstructiva CrónicaAsmática; Efectos. 


\section{INTRODUCTION}

Chronic obstructive pulmonary disease (COPD) is one of the most common diseases in the lungs, it is a kind of irreversible and destructive respiratory disease due to airflow restriction, with a morbidity of about 8.2\% and a fatality rate of close to $1.6 \%$. Therefore, it is urgent to find a treatment plan to enhance lung function and exercise ability of patients. There are many causes of copd, including: Environmental causes of excessive dust inhalation in the air, smoking, respiratory infections, and work in special populations.' In short, the etiology of this kind of disease is varied and complex, and it is not clear at present. Meanwhile, the incidence of chronic obstructive lung disease is about 9\% in China, but improper treatment will directly cause death of patients, with the fatality rate reaching $2 \%$. Li, Z., Li, Y. et al proposed that currently, drug therapy is the main treatment for alleviating such patients. Modern medicine indicates that in addition to drug therapy, the treatment of chronic obstructive pulmonary disease should also find a more suitable treatment for patients' physical conditions. ${ }^{2}$

\section{METHOD}

\section{General Information}

From December 2013 to June 2015, 156 patients with chronic obstructive pulmonary disease were selected from relevant departments of the hospital. ${ }^{3}$ The patients were $43-85$ years old, with an average age of $(56.12 \pm 4.76)$ years. The course of disease ranged from 4.5 months to 16 years, with an average of (12.5 \pm 5.5$)$ years. All subjects were randomly divided into 39 cases of control group A, control group B, control group $C$ and experimental group, the general data of the four groups were compared, and there was no statistical significance $(P>0.05)$.

\section{Methods}

Control group A: Routine drug treatment. Control group B: On the basis of group A, supplemented with traditional Chinese medicine qigong training. ${ }^{4}$ Control group C: On the basis of group A, supplemented with modern respiratory rehabilitation training. Experimental group: Group A and B were treated on the basis of modern respiratory rehabilitation training.

\section{Observation Indicators}

The indexes related to blood gas analysis of patients before and after treatment were observed and recorded, 6MWD was measured, CAT and MMRC scores were evaluated and BODE index was calculated by questionnaire survey. ${ }^{5}$

\section{Statistical Methods}

All data were statistically analyzed, mean \pm standard deviation $(x \pm s)$ was used for measurement data, the independent sample $T$ test was used to compare the measurement data between groups, the counting data was expressed as percentage (\%) and the $X^{2}$ test was used. $P<0.05$ was considered statistically significant.

\section{Comprehensive evaluation criteria for copd patients}

According to the global copd Initiative, once copd is diagnosed, a comprehensive assessment should be conducted based on the individual condition of the patient to develop effective care plans. The comprehensive evaluation of copd patients is based on the patient's symptoms, the risk of acute exacerbation and the severity of airflow restriction. ${ }^{6}$ The goal is to determine the severity of the disease, with the ultimate goal of directing the patient to home care.

\section{Symptom assessment}

At present, the main use of copd patients self-assessment test and intensive evaluation of patients' symptoms.

\section{Assessment of air flow limitation}

The degree of airflow restriction in copd patients was determined by measuring the patient's ${ }^{F E} V_{I}$ after inhaling bronchodilators. The specific grading standards are shown in Table 1. All patients diagnosed with copd were satisfied with:

${ }^{F E} V_{I} / \mathrm{FVC}<0.70$

${ }^{F E} V_{I}$ refers to the patient's maximum expiratory volume. FVC refers to forced lung capacity, which is the maximum amount of air that can be exhaled as soon as possible after inhaling as much as possible. ${ }^{F E} V_{I} \%$ pred represents ${ }^{F E} V_{I}$ as a percentage of the estimated value, that is, ${ }^{F E} V_{I}$ compared to its own estimated value. The effect of lung function training data changes with the extension of exercise time, as shown in Figure 1.

Table 1. Degree of airflow restriction in copd patients.

\begin{tabular}{c|c|c}
\hline $\begin{array}{c}\text { Pulmonary function } \\
\text { grading }\end{array}$ & $\begin{array}{c}\text { Degree of airflow } \\
\text { restriction }\end{array}$ & The judgment standard \\
\hline GOLD1 & Mild & ${ }^{F E} V_{I} \%$ pred $\geq 80 \%$ \\
\hline GOLD2 & Moderate & $50 \% \leq{ }^{F E} V_{I} \%$ pred $<80 \%$ \\
\hline GOLD3 & Severe & $30 \% \leq{ }^{F E} V_{I} \%$ pred $<50 \%$ \\
\hline GOLD4 & Very severely & ${ }^{F E} V_{I} \%$ pred $<30 \%$ \\
\hline
\end{tabular}

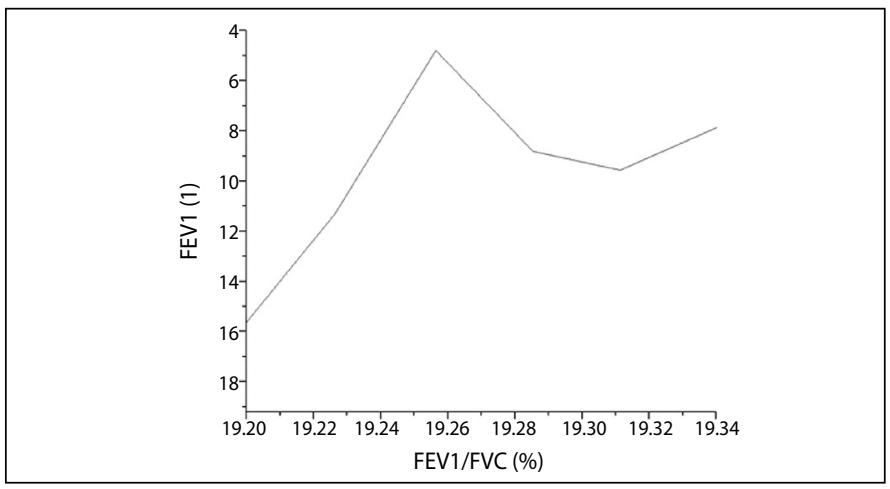

Figure 1. Analysis chart of pulmonary function data report.

\section{RESULTS}

\section{Compare the changes of blood gas analysis indexes in the four groups}

By comparing the blood gas analysis indexes of the four groups, it can be seen that the variation range of blood gas analysis indexes of the experimental group trained by integrated Chinese and western medicine was significantly better than that of the control groups $\mathrm{A}, \mathrm{B}$ and $\mathrm{C}$, such as $\mathrm{PaCO} 2, \mathrm{PaO} 2, \mathrm{SaO} 2$ and $\mathrm{pH}$, with significant differences. (Table 2)

\section{Comparison of pulmonary function changes among the four groups}

The improvement of lung function of the four groups was detected, and it was found that the improvement of lung function of the experimental group using integrated Chinese and western medicine training program was significantly better than that of the other three groups of control group, with statistical significance $(P<0.05)$. (Table 3$)$.

\section{DISCUSSION}

Although drug therapy can alleviate the clinical manifestations of patients, the effect of respiratory rehabilitation treatment for patients is not good, at this time, different methods of respiratory rehabilitation training programs have been widely noticed by the medical community. It was found that both tcm qigong therapy and modern respiratory rehabilitation therapy could 
Table 2. Comparison of blood gas analysis results between the four groups before and after treatment $(x \pm s)$.

\begin{tabular}{|c|c|c|c|c|c|}
\hline Group & & $\mathrm{PaCO} 2(\mathrm{mmHg})$ & $\mathrm{PaO} 2(\mathrm{mmHg})$ & $\mathrm{SaO2}(\%)$ & PH \\
\hline \multirow{2}{*}{$\begin{array}{l}\text { Experimental } \\
\text { group }\end{array}$} & $\begin{array}{l}\text { Before the } \\
\text { treatment }\end{array}$ & $82.36 \pm 18.65$ & $59.68 \pm 12.42$ & $0.88 \pm 0.17$ & $7.27 \pm 0.02$ \\
\hline & $\begin{array}{c}\text { After } \\
\text { treatment }\end{array}$ & $62.86 \pm 10.37$ & $79.26 \pm 13.88$ & $0.99 \pm 0.06$ & $7.36 \pm 0.06$ \\
\hline \multirow{2}{*}{ Contrast } & $\begin{array}{l}\text { Before the } \\
\text { treatment }\end{array}$ & $82.08 \pm 18.79$ & $59.85 \pm 12.91$ & $0.86 \pm 0.12$ & $7.26 \pm 0.04$ \\
\hline & $\begin{array}{c}\text { After } \\
\text { treatment }\end{array}$ & $70.13 \pm 12.45$ & $70.05 \pm 13.97$ & $0.90 \pm 0.05$ & $7.29 \pm 0.05$ \\
\hline \multirow{2}{*}{ Contrast } & $\begin{array}{l}\text { Before the } \\
\text { treatment }\end{array}$ & $82.12 \pm 18.35$ & $59.32 \pm 11.96$ & $0.87 \pm 0.15$ & $7.21 \pm 0.02$ \\
\hline & $\begin{array}{c}\text { After } \\
\text { treatment }\end{array}$ & $68.23 \pm 11.23$ & $71.36 \pm 13.52$ & $0.91 \pm 0.03$ & $7.25 \pm 0.04$ \\
\hline \multirow{2}{*}{ Contrast } & $\begin{array}{l}\text { Before the } \\
\text { treatment }\end{array}$ & $82.56 \pm 17.96$ & $59.23 \pm 12.32$ & $0.87 \pm 0.16$ & $7.19 \pm 0.05$ \\
\hline & $\begin{array}{c}\text { After } \\
\text { treatment }\end{array}$ & $68.26 \pm 9.52$ & $73.23 \pm 10.98$ & $0.92 \pm 0.02$ & $7.22 \pm 0.03$ \\
\hline
\end{tabular}

Table 3. Comparison of pulmonary function changes among the four groups $(x \pm s)$.

\begin{tabular}{c|c|c|c|c|c}
\hline Group & Time & CAT & MMRC & BODE index & $6 \mathbf{M W D}(\mathbf{m})$ \\
\hline $\begin{array}{c}\text { The } \\
\text { experimental } \\
\text { group }\end{array}$ & Before the treatment & $19.8 \pm 4.1$ & $2.2 \pm 0.3$ & $4.3 \pm 1.3$ & $280 \pm 38$ \\
\cline { 2 - 6 } & After treatment & $16.5 \pm 3.2$ & $1.8 \pm 0.1$ & $3.9 \pm 1.2$ & $311 \pm 29$ \\
\hline \multirow{2}{*}{ Against A } & Before the treatment & $20.9 \pm 4.2$ & $2.1 \pm 0.3$ & $4.2 \pm 1.1$ & $278 \pm 36$ \\
\cline { 2 - 6 } & After treatment & $21.1 \pm 4.7$ & $2.2 \pm 0.3$ & $4.2 \pm 1.3$ & $276 \pm 42$ \\
\hline \multirow{2}{*}{ Against B } & Before the treatment & $18.3 \pm 3.7$ & $2.2 \pm 0.4$ & $4.2 \pm 1.3$ & $287 \pm 32$ \\
\cline { 2 - 6 } & After treatment & $17.2 \pm 4.2$ & $1.9 \pm 0.4$ & $3.8 \pm 1.1$ & $292 \pm 32$ \\
\hline \multirow{2}{*}{ Against C } & Before the treatment & $19.6 \pm 3.4$ & $2.5 \pm 5$ & $4.3 \pm 1.1$ & $284 \pm 33$ \\
\cline { 2 - 6 } & After treatment & $17.3 \pm 3.1$ & $1.9 \pm 0.3$ & $4.1 \pm 1.3$ & $309 \pm 28$ \\
\hline
\end{tabular}

Note: Compared with control group A, *P $<0.05$; Compared with control group B after treatment, $\# \mathrm{P}<0.05$. Compared with control group $C$ after treatment, $\Delta \mathrm{P}<0.05$. significantly improve the clinical manifestations of dyspnea and enhance the patients' motor ability, but there was no significant difference in the clinical effects of the two treatment programs. ${ }^{8}$ The blood gas analysis indexes of patients in the four groups were investigated after treatment in different groups, the variation range of blood gas analysis indexes of experimental groups trained by integrated Chinese and western medicine was significantly better than that of control groups $\mathrm{A}, \mathrm{B}$ and $\mathrm{C}$, such as $\mathrm{PaCO} 2, \mathrm{PaO} 2, \mathrm{SaO} 2, \mathrm{pH}$, etc., with statistical significance $(P<0.05) .{ }^{9}$ It shows that the training program of integrated Traditional Chinese and western medicine significantly improved the blood gas analysis index of patients. Further comparison of the improvement of lung function of the four groups showed that the improvement of lung function of the experimental group using integrated Chinese and western medicine training program was significantly better than that of the other three groups of control group, with statistical significance $(P<0.05) .{ }^{10}$ This is because the program of integrated Traditional Chinese and western medicine is beneficial to the enhancement of the patient's lung function, and the improvement of the patient's 6MWD index indicates that this program enhances the patient's exercise endurance and endurance, and improves the patient's difficult respiratory symptoms. Among them, traditional Chinese medicine qigong treatment can better adjust the patient's psychological state, avoid the patient's bad mood, and modern rehabilitation treatment is conducive to the improvement of the patient's motor ability.

\section{CONCLUSION}

In conclusion, in the clinical treatment of motor function in patients with chronic obstructive pulmonary disease, the application of integrated Traditional Chinese and western medicine in respiratory rehabilitation training has significant clinical effects, which can effectively improve the relevant clinical indicators of patients, and should be widely promoted.

All authors declare no potential conflict of interest related to this article

AUTHORS' CONTRIBUTIONS: Each author made significant individual contributions to this manuscript. Jingao Qin: writing and performing surgeries; Zhen Wan: data analysis and performing surgeries, article review and intellectual concept of the article.

\section{REFERENCES}

1. Ni L, Yuan W, Chen L, Han C, Chen H. Combating covid-19 with integrated traditional chinese and western medicine in china. Acta Pharmaceutica Sinica B. 2020;10(7):1149-62.

2. Li Z, Li Y, Wang B. Treatment of 2019 novel coronavirus pneumonia based on the theory of "three syndromes and three methods". Chinese Critical Care Medicine. 2020;32(1):5-7.

3. Committee China Association Of Integrative Medicine Emergency Medicine, Editorial Committee Of Chinese Journal Of Integrated Traditional And Western Medicine, Li Z, Wang D, Li Y. Expert consensus on diagnosis and treatment of septic shock with integrated traditional chinese and western medicine. Zhonghua Wei Zhong Bing Ji Jiu Yi Xue. 2019;31(11):1317-23.

4. Wang KF, Chen YD, Mo LQ, Zhang Z, Wu SX. Integrated traditional chinese and western medicine in hepatocellular carcinoma treatment. World Chinese Journal of Digestology. 2019;27(7):459-66.

5. Tan MS, Atul G, Kuniyoshi A, Zhang, F, Zhao Y. Clinical practice guideline of integrated traditional chinese and western medicine:atlantoaxial dislocation (AAD) (2019). Zhongguo gu shang: China journal of orthopaedics and traumatology. 2020;33(1):27-37.

6. Miao J, Wang L, Cui HT, Guo LY, Jia JW. Study on the effect of integrated traditional chinese and western medicine in the treatment of brucellosis. Zhonghua lao dong wei sheng zhi ye bing za zhi = Zhonghua laodong weisheng zhiyebing zazhi. Chinese journal of industrial hygiene and occupational diseases. 2021;39(4):253-7

7. Xing $Q$, Fu L, Yu Z, Zhou X. Efficacy and safety of integrated traditional chinese medicine and western medicine on the treatment of rheumatoid arthritis: a meta-analysis. Evidence-based Complementary and Alternative Medicine. 2020;2020(30):1-15.

8. Noguchi M, Hoshino Y, Yaguchi K, Hizume E, Yuzuriha S. Does aggressive respiratory rehabilitation after primary nuss procedure improve pulmonary function? - sciencedirect. Journal of Pediatric Surgery. 2020;55(4):615-8

9. Mazza A, Paneroni M, Vitacca M. The new concept of rehabilitation space in the era of the digital health in cardio-respiratory rehabilitation. Giornale italiano di medicina del lavoro ed ergonomia. 2019;41 (2):121-4.

10. Jipa-Dun D, Croitoru A, Bezdedeanu A. The effects of a respiratory rehabilitation programme on body composition. Pneumologia. 2020;69(1):29-36 